\title{
Gereformeerde gemeente-opbou?
}

\section{'n Evaluering van bestaande definisies binne die geledere van die Gereformeerde Kerke in Suid-Afrika}

\author{
J.L. du Plooy en C.J.H. Venter \\ Dept. Diakoniologie \& Missiologie \\ Potchefstroomse Universiteit vir $\mathrm{CHO}$ \\ POTCHEFSTROOM
}

\begin{abstract}
Reformed congregation building? A survey of current definitions within the ranks of the Gereformeerde Kerke in Suid-Afrika

In this article current defimitons of congregation building (church grow'th) in the ranks of the Gereformeerde Kerke in Suid-Afrika are described. Several contributions of Reformed ("Gereformeerde") theologians concerning these definitions are considered and craluated. The possibility of dufferem points of departure is discussed. In conclusion, several suggestions concerning a defintion of congregation building are made for funre consideration.
\end{abstract}

\section{Inleiding}

Met die instelling van die vak Gemeentebou aan die verskillende teologiese fakulteite van die Nederduitse Gereformeerde Kerk (NGK) het daar vanaf die tagtigerjare 'n besondere opbloei in belangstelling en literatuur oor die onderwerp gemeentebou in Suid-Afrika ontstaan (vgl. Nel, 1994:2; Erasmus 1994:1). Hierdie groot belangstelling is vanuit die buiteland gestimuleer en verder aangewakker (Erasmus, 1994:2). Die aktiwiteite van die Church Growth Movement (CGM) van Amerika sedert die vyftigerjare het wêreldwyd invloed uitgeoefen. Ook in Duitsland (vgl. F. Schwarz en C.A. Schwarz se Theologie der Gemeindeaufhaus van 1987) en Nederland is daar 'n opbloei in die belangstelling en navorsing oor gemeente-opbou (Te Velde, 1992:7). 'n Groot hoeveelheid wetenskaplike tydskrifartikels is plaaslik gepubliseer, en dek 'n breë spektrum van onderwerpe binne hierdie veld (vgl. Du Plooy, 1994:7, 52-81 en Erasmus, 1994:90-108). Vanuit die geledere van die NGK (Erasmus, 1994:23) en die Gereformeerde Kerke in Suid-Afrika (GKSA) het 'n hele aantal teoloe reeds gepromoveer binne die veld van gemeente-opbou (Du Plooy, 1994:7-8).

Hierdie artikel spits hom toe op die stand van navorsing in die GKSA oor gemeente-opbou, en in die besonder oor die definiering van gemeente-opbou binne die GKSA. Dit blyk wel problematies te wees presies wat onder gemeenteopbou verstaan word, en wat die plek - indien enige - van gemeente-opbou as 
vorm van Woordbediening in die plaaslike gemeente behoort te wees. Daarmee hang saam die problematiek van wat die plek van gemeente-opbou binne die teologiese ensiklopedie is - indien dit wel 'n staanplek verdien. Hierdie artikel het ten doel om bogenoemde aspekte van die besinning oor gemeente-opbou binne die geledere van die GKSA na te gaan en te evalueer. Die voorlopige hipotese van hierdie artikel is die volgende:

* 'n Onduidelikheid blyk in die definisie(s) van gemeente-opbou binne die literatuur van die GKSA.

* Die wetenskapstatus van gemeente-opbou as teologiese dissipline is nog nie duidelik geformuleer is nie, hoofsaaklik as gevolg van hierdie onduidelike definisie.

Die term Gereformeerd(e) word in hierdie artikel konsekwent in onderskeiding gebruik van gereformeerd(e). Die term Gereformeerd(e), word gebruik as beskrywend van die GKSA, terwyl gereformeerde(e) gebruik word as beskrywend van die breër gereformeerd-Protestantse teologie/gebruike/tradisies.

\section{Bydraes van Gereformeerde teoloæ}

Daar bestaan reeds eksegetiese, ekklesiologiese en diakoniologiese bydraes wat toepaslik is op die gebied van gemeente-opbou. Die volgende bydraes word vervolgens temagewys genoem (uiteraard nie almal nie):

\subsection{Klem op die individuele lidmaat}

J.D. du Toit skryf in 1911 reeds in sy inougurele rede oor die sestiende-eeuse profesie. Daarin pleit hy hartstogtelik vir die inwerkingstelling van die diens van die gelowige - veral as profeet (in Du Toit, 1977:75-97). In 1959 vra S.C.W. Duvenage (1959:173-188) by die eeufeesherdenking van die kerk die aandag vir die amp van die gelowige. L. Floor (1971) en J. Malan (1979) pleit ook vir die aktivering van die amp van die gelowige. J.J. van der Walt (1976) formuleer in sy proefskrif sy verset teen ampsoorheering in die kerk.

In die tagtigerjare het daar in Gereformeerde kerke groot belangstelling ontstaan in die Ontdek-jou-gawes-kursus (vgl. D.C. Coetsee \& D. Postma se artikel in Die Kerkblad van 4 April 1984). Daaruit blyk die hernude ywer vir die funksionering van die amp van die die gelowige.

\subsection{Impulse vanuit die hoek van evangelisering}

Aan die begin van die tagtigerjare is verskeie werkswinkels landswyd gehou om evangelisasie volgens die EE3-metode te bevorder Gereformeerdes het ook hieraan deel gehad. Die landswye reaksie hierop lei tot verskeie besware op die 
tafel van die Nasionale Sinode van 1982. Die uiteinde was dat die kursus teologies as onvoldoende beoordeel is en kerke en ampsdraers en lidmate opgeroep is om nie daaraan deel te hê nie (Handelinge, 1982). Dieselfde Sinode besluit egter om Evangelistiek tot volwaardige vak aan die Teologiese Skool te Potchefstroom uit te bou. 'n Aantal teoloë voel die leemtes en spanninge van die EE3-kursus aan en verwerk die kursus om die leemtes op te vul en spanninge daaruit te verwyder met die oog op die landswye implementering daarvan (vgl. Buys, P.J., 1983). P.J. Buys doen daama op magistervlak 'n studie oor Die aard van die verbond en die implikasies daarvan vir Evangelisasie (1984); en daarna op doktorale vlak oor Die verhouding tussen gemeenteopbou en evangelisering: in eksegetiese ondersoek na die betekenis van die tersaaklike woorde in die Nuwe Testament en die implikasies daarvan vir die verhouding tussen die bewaring en die vermeerdering van die kerk (Buys, 1989). In sy proefskrif stel hy dat evangelisering gewoon 'n aspek van gemeente-opbou is en wat voorsiening moet maak vir die voortgaande onderrig van gelowiges vir hulle dienswerk biune die kerk (bewaringsaspek), maar ook vir hulle dienswerk in die kwantitatiewe opbou van die kerk met die oog op die vermeerdering van die kerk (Buys, 1989:257). I.J. van der Walt besef die leemte aan toerustingsmateriaal en skryf 'n onvattende studie oor evangelisering: Die evangelie aan afgedwaaldes: Handleiding vir Evangelisasie (Van der Walt, 1985). Meer onlangs skryf J. Oostenbrink (1994) in sy meestersverhandeling oor Kleingroepevangelisasie in die stad. P.J. Buys en C.J.H. Venter (1994:331) stel in 'n navorsingsartikel die probleem dat Gerefonneerde kerke nie groei nie. Hulle stel die hipotese dat die vermoë van 'n gemeente om nuwe gelowiges effektief in die gemeenskap van gelowiges te assimileer, saamhang met die hele funksionering van die gemeente. Buys en Venter beklemtoon in die artikel die verband tussen die bewarende en vermeerderende aspekte van gemeente-opbou, en beklemtoon dat in die verskillende aspekte van gemeentelike praktyk die verband doelbewus aandag moet geniet (Buys \& Venter, 1994:348).

\subsection{Klem op die taak en roeping van die kerk}

Rondom die eeufeesvierings van die GKSA in 1959 het daar egter reeds 'n hele aantal publikasies verskyn, waarvan sommige uiteraard ingestel was op 'n besinning oor die taak en roeping van die kerk, en wat analities-krities die status quo van die Gereformeerde kerklike praktyk onder die loep geneem het. P.J. Coetzee (1959:288-289) drung aan op voortdurende reformasie asook op die amp van die gelowige wat die Woord met gesag moet uitdra. Ook in 1959 skryf W.J. de Klerk (1959.5) oor 'n aantal onderwerpe waarin hy sy protespoging verwoord "teen die vervlakking en annoede in die harte van mense wat die genade van God gesmaak het en die stem van Christus gehoor het". In 1964 skryf De Klerk in 'n meer krities-ontledende styl W'ending? Vernuwingsgesprekke oor die Gereformeerde kerkpraktyk. Sake wat vandag nog in die brandpunt in gemeente-opbou 
staan, kom hier ook aan die orde, naamlik die gemeente as liefdesgemeenskap (De Klerk, 1964:19-20) en die amp van die gelowige (De Klerk, 1964:27, 105).

In die tagtigerjare gaan 'n aantal protesstenıme op teen aspekte van die kerklike praktyk van die GKSA. L.F. Schulze (1980:3) pleit vir Skriftuurlike gemeenteopbou wat die onderskeid tussen opbou en uitbou Skrifmatig hanteer. J.A. van Rooy $(1984 \mathrm{~b}: 1,16)$ wys op die profetiese en priesterlike roeping van elke lidmaat nadat hy ernstig waarsku teen die gevaar van "predikantekerk", onmondigheid by die lidmaat en gebrekkige aanwending van die genadegawes van die Gees (Van Rooy, 1984a:2).

\subsection{Klem op die gemeente as gemeenskap}

In die Gereformeerde denke is algaande ook aandag gegee aan die kerk as die gemeenskap van die heiliges. V. Combrink (1987:10-13) gaan die begrip koinonia na en toon die struikelblokke in die verwesenliking van die gemeenskap aan, waaronder tradisionalisme en verwêreldliking as struikelblokke geld. Hy beveel die huisgemeente as konkrete patroon vir geloofsgemeenskap aan. $\mathrm{N}$. van der Walt (1980:21) wys op koinonia as 'n onmisbare kenmerk van die kerk. J.C. Coetzee (1980:104-113) skryf oor die diakenamp as die amp van die liefdesgemeenskap - 'n artikel wat saamhang met 'n herlewing van die diakenamp in die GKSA juis met die oog daarop om koinonia te bevorder. C.J.H. Venter (1988a:10-27) laat val die klem in sy artikel, "'n Nuwe-Testamentiese profiel van 'n gemeente wat homself opbou" op die gemeente as geloofsgemeenskap. In dié profiel is 'n klemverskuiwing merkbaar vanaf die blote amp van die gelowige na diè van die gemeente as geloofsgemeenskap.

\subsection{Sinodale kennisname van dalende lidmaattalle}

Tydens die sitting van die Nasionale Sinode van die GKSA in 1994 besluit die Sinode om sy kommer oor die tendens van dalende lidmaattalle binne die GKSA uit te spreek. Gevolglik gee dié Sinode opdrag aan deputate om "met inagneming van wat tans op teologiese en kerklike terrein hieroor gedoen en gepubliseer word, 'n grondige en omvattende studie te mak van die huidige tendens van lidmategetalle in GKSA wat besig is om te daal; die moontlike oorsake daarvan en hoe die situasie op 'n Skrifgetroue wyse aangespreek kan word" (Handelinge, 1994:619). Hierdie besluit moet as besliste winspunt aangeteken word, en kan in dieselfde asem genoem word met soortgelyke optrede binne die Nederlandse Hervormde Kerk (van Nederland), asook die soortgelyke studie in die Gereformeerde Kerken (Synodaal) en die Kerkspieels van die NGK van onderskeidelik 1981, 1985 en 1989 (Erasmus, 1994:21). 


\subsection{Teologiese onderbou vir gemeente-opbou}

Die studie van W.J. Snyman (1977:35-50) Die gebrulk van die woord 'kerk' in die Nuwe Testament en die doktorale studie van A. le R. du Plooy (1982), Kerkverhand: 'n Gereformeerd-kerkregtclike studie, is nie primêr geskryf met die oog op die onderwerp van gemeente-opbou nie. Die verband tussen ekklesiologie en gemeente-opbou is egter onses insiens van so 'n groot belang dat die resultate van die studie noodsaaklik vir ons onderwerp is. 'n Skriftuurlike begrip van kerk is onmisbaar in gereformeerde gemeente-opbou. Die eksegetiese werk van Snyman (1977) waarin hy die onderskeid en verband van die plaaslike en universele kerk aangetoon het, het die weg gebaan vir verdere dinamiese denke in hierdie verband. B. Spoelstra het in 'n aantal studies die klem laat val op die feit dat die kerkbegrip van Gereformeerdes Skrifuurlik-bepaal is (Spoelstra, 1984:22-24). Hy kom in verset teen die struktuurmatige verstaan van kerkwees waarin die dinamiese kerk as vergadering van gelowiges in statiese strukture stol, omdat die institusionele "kerk" die mense verplaas wat die kerk moes wees (1986:15). Hy lewer 'n pleidooi dat kosmetiese veranderinge aan die liturgie, bedieningspatrone of gemeentemodelle nie genoegsaam is om tot die wortel van die probleem van kerklike verval deur te dring nie (Spoelstra, 1994:14-15). Daarmee is duidelik gemaak dat die kerk 'n pneumatologiese werklikheid is wat Skrifmatig benader moet word en nie primêr sosiologies, statisties of antropologies nie. Verdere besinning is onses insiens nodig om die plek van die handelingswetenskappe in gemeente-opbou te bepaal.

B. Spoelstra (1991:206-226; 1992:299-320) vта in 'n aantal artikels kritiese vrae oor die ontwikkelinge rondom gemeente-opbou. Sy vrae handel oor die ensiklopediese plek van Gemeente-opbou en van Diakoniologie, die verhouding van die Ekklesiologie tot Diakoniologie, en oor die kerkbegrip wat in die gereformeerde kerke funksioneer - na aanleiding van die besinning oor gemeenteopbou en die plek daarvan in die teologiese ensiklopedie.

In 1971 skryf P.C. Snyman 'n navorsingsartikel oor “'n Ontleding van die prediking in die Nuwe Testament met die oog op die opbou van die kerk as missionêre probleem". Hy onderskei tussen "voordoopse" en "nadoopse" prediking waar laasgenoemde as "stigtelike en opbouende" prediking genoem kan word wat 'n meer omlynde gestalte aanneem met die oog op die opbou van die gemeente (Snyman, 1971:26). Een van die Gereformeerde teoloë wat gemeenteopbou, die mondigheid van die gelowige en toerusting daartoe aktief sedert die sewentigerjare bepleit het, was J.J. van der Walt. Vir hom gaan dit om Bybelse vernuwing in die herderlike bediening, en Bybelse vernuwing in die praktyk van die kerk. Verskeie publikasies met hierdie doel voor oë verskyn van hom, onder meer Christus as Hoof van die Kerk en die preshiteriale kerkregering (1976), "Die verhouding van die Diakoniologie tot die ander teologiese dissiplines" (Van der Walt, 1981) - in hierdie artikel word belangrike riglyne ten opsigte van die 
kenteoretiese basis van Diakoniologie gegee. Ten slotte noem ons ook Teen hierdie strominge die kerk (Van der Walt, 1986) waarin die wese van kerkwees bespreek word. Van 'n formele definisie van gemeentebou as vak of as bediening is tot op hierdie stadium egter nie sprake nie.

C.J.H. Venter skryf ook oor die opbou van die kerk. Hiervan dien as voorbeeld Gemeente-opbou in die lig van Hebreërs (1986) waarin hy die boek Hebreërs ontleed met die oog op die opbou van die gemeente. Venter (1988a) kom tot 'n selfstandige definisie van gemeente-opbou in nog 'n publikasie oor hierdie aspek, “'n Nuwe-Testamentiese profiel van 'n gemeente wat homself opbou". Venter tree ook op as redakteur van die publikasie God bou op deur sy Woord (1988b), 'n huldigingsbundel aan J.J. van der Walt wat as sentrale tema die opbou van die kerk het.

F. Buys (1988) evalueer die CGM in sy artikel, "Kerkgroei: 'n Kritiese evaluering van die kernaspekte van die Church Growth Movement", en stip 'n aantal negatiewe en positiewe eienskappe van die beweging aan.

\subsection{Navorsing oor gemeente-opbou}

'n Aantal teoloë van die GKSA promoveer in verskillende dissiplines oor die opbou van die kerk: A.G.S. Venter (1986) met 'n Nuwe-Testamentiese studie: Die werk van die Heilige Gees in die opbou van die kerk volgens Handelinge en V. Combrink (1993) met 'n Nuwe-Testamenties/Diakoniologiese studie: Die betekenis van die eskatologie in die Kolossensebrief vir gemeente-opbou: 'n diakoniologiese ondersoek. G.C.P. Labuscagne (1988) promoveer in die Homiletiek met Die plek en betekenis van die prediking in die opbou van die gemeente. E.J. Tiemensma (1989) skryf sy verhandeling in die Pastoraat: Huweliksorg in gemeente-opbou: geloofsgroei as grond on inhoud van die pastorale begeleiding van man en vrou in die huwelik en T.C. de Klerk (1990) skryf in Liturgiek oor Die rol van eredienssang in die opbou van die gemeente.

\subsection{Samevatting}

Dit blyk dat daar genoegsame en diepgaande besinning binne die GKSA gedoen is om vanuit Gereformeerde kant 'n belangrike bydrae tot gemeente-opbou te maak. Die bestaande navorsing het belangrike eksegetiese, ekklesiologiese en diakoniologiese bydraes na vore gebring, en sommige daarvan kan met groot vrug verder ontgin en toegepas word op die gebied van geıneente-opbou.

Vervolgens word aandag gegee aan die definiëring van gemeente-opbou in die publikasies vanuit die geledere van die GKSA. 


\section{Definiëringsproblematiek van gemeente-opbou}

\subsection{Gemeente-opbou - 'n aanvaarbare term?}

Te Velde $(1993 a: 13,14)$ wys op die verwarrende gebruik van die woord "gemeenteopbouw" wanneer elke kerklike aktiwiteit (soos bv. 'n geldinsamelingsprojek) "gemeente-opbou" genoem word maar in werklikheid weinig of niks met 'n "beleidsmatige aanpak" (vir intensiewe en ekstensiewe groei van die kerk) te doen het nie. Nel (1987:1) stel onses insiens die korrekte siening oor gemeente-opbou as hy sê dat dit voor die hand liggend is dat byvoorbeeld die prediking die opbou van die gemeente dien (en so ook die pastorale sorg) maar dat dit nie korrek is om sonder meer te sê dat prediking gelyk aan gemeenteopbou is nie. Die volgende stelling kan met instemming aangehaal word: "Die totale bediening moet die gemeente bou, maar Gemeentebou is nie in sy totaliteit bloot alles wat in belang van die opbou van die gemeente gebeur nie" (Nel, 1987:1). Ook Te Velde (1989:29) merk op dat "niet alle werk in de kerk kan 'gemeenteopbouw' heten". Te Velde (1992:29) beskou "gemeente-opbou" as 'n "onbescheiden en pretentieuze aanduiding" waarby kritiese aanmerkings gemaak moet word, maar meen tog dat die tern wel bruikbaar is (Te Velde, 1992a:29. 30). Die bruikbaarheid van die term vir hom blyk duidelik uit die titel van sy vierledige werk: Gemeenteopbouw. Dit blyk ook baie duidelik uit sy inougurele rede waarin hy poog om vir "Gereformeerde gemeenteopbouw" as 'n nuwe teologiese vak 'n koersbepaling aan te dui (Te Velde, 1989)

In terme van Te Velde se definisie hierbo is gemeente-opbou 'n relatief nuwe saak in die kerk. Hierdie definisie is egter problematies vir die onderhawige besinning. Daar bestaan eerstens nie in die teologiese raamwerk van die GKSA so 'n vak nie, en tweedens blyk uit bestaande literatuur van die GKSA nie algemene instemming met die tweeledige definiëring van gemeente-opbou (as 'n gestalte van Woordbediening en as ' $n$ teologies-definieerbare dissipline) nie.

\subsection{Definisie van gemeente-opbou in die gepubliseerde literatuur vanuit die GKSA}

Die volgende inligting oor die definiëring van gemeente-opbou blyk uit die bestaande navorsing in Gereformeerde geledere

* A.G.S. Venter skryf in 1986 sy proefskrif Die werk van die Heilige Gees in die opbou van die kerk volgens Handelinge. Hierdie studie is 'n eksegetiese ondersoek na die gegewens wat Handelinge bied oor die werk van die Heilige Gees in die opbou van die kerk (Venter, 1986:208). Venter sien "opbou" as die "versorging van die mense wat reeds aan die kerk behoort, en is dus intern op die lewe in die gemeentes gerig. Opbou word van die uitbreiding (uitbou) 
van die kerk onderskei. In hierdie verband word opbou en uitbou onderskei maar nie finaal geskei nie" (Venter, 1986:10).

* G.C.P Labuscagne bied onder Gereformeerde teoloè die mees omvattende definisie en bespreking van die proses van die opbou van die gemeente. Hy verklaar die opbouproses as die proses van opbou of groei in volwassenheid na Christus toe - die opbou en groei van elke gelowige en die gemeente as geheel (Labuscagne, 1988:6). Volgens hom rus die opbou van die gemeente op die veronderstelling dat die Nuwe-Testamentiese gemeente nie "terstond tot sy einddoel en volkomenheid gekom het nie" (Labuscagne, 1988:68). Die gemeente leef dus in die spanning van "die 'reeds' van die voltooide versoeningswerk van Christus" (Labuscagne, 1988:69), en die "nog nie" van die onvolkomenheid wat die gemeente in die sondige bedeling aankleef.

Labuscagne (1988:69) vestig die aandag daarop dat die "opbou van die gemeente as bevestiging in Christus nie 'n statiese toestand of 'n vanselfsprekendheid is nie. Die opbou ... is alleen van toepassing op die gemeente omdat en in soverre hulle gelowig uit die Woord van God leef'. Juis daarom word die opbou van die gemeente as 'n dringende imperatief verkondig, 'n imperatief wat gegrond is en plaasvind op die indikatief van die opbou. Labuscagne toon aan dat die doel van gemeente-opbou volgens Efesiërs 4 die volheid in Christus is, "die volle bewuswording, die volle kennis en insig in die allesomvattende betekenis van Christus" (Labuscagne, 1988:71, 72). Hy wys daarop dat die volheid in Christus tegelyk gawe en doel is, maar dat die "gawe van Christus as volheid ... in die gestalte van 'n organiese groeiproses gerealiseer en geaktualiseer" word (Labuscagne, 1988:72).

* V. Combrink (1993:5-6) beskryf gemeente-opbou as die "eskatologiese gebeure in die tussentyd (dit wil sê tussen hemelvaart en wederkoms) waardeur God Drie-enig sy gemeente universeel en plaaslik, gesamentlik en individueel, ekstensief in getalle en intensief in geloof, hoop en liefde opbou (toerus) met sy Woord deur middel van gawes (waaronder dienste) met die doel om Homself te verheerlik deur middel van gelowiges se diensbaarheid in sy koninkryk".

Dit is nie duidelik uit bogenoemde definisie of Combrink met opbou mik op toerus nie. Sou die twee terme dan dieselfde lading dek?

* C.J.H. Venter (1986:1-2) omskryf gemeente-opbou soos volg: "Gemeenteopbou is die beplande, gekoordineerde en sistematiese toerusting van gelowiges deur die gawes (i.c. ampte) deur middel van die Woord in verskillende gestaltes van Woordbediening tot opbou en groei in persoonlike geloof en geloofsgemeenskap met God en met mekaar." Ook in hierdie definisie word 'n sterk band gelê tussen gemeente-opbou en toerusting. 
* 'n Soortgelyke definisie word in Die Kerkblad gegee na aanleiding van 'n vergadering van Klassis Potchefstroom: gemeente-opbou word gesien "as die toerusting wat aan die ampsdraers in die kerke gegee word vir opbouing in die geloof om daardeur die lidmate vir hulle dienswerk te bekwaam" (Anon., 1984:3).

* Tiemensma (1989) se pastorale studie oor huweliksorg word in verband met die opbou van die gemeente gebring, maar hy gee geen duidelik-omlynde definisie van gemeente-opbou nie. Dieselfde geld ook vir die liturgiese studie van De Klerk (1990) wat primêr oor eredienssang handel, maar in die titel van sy verhandeling, Die rol van die eredienssang in die opbou van die gemeente, word eredienssang in verband gebring met die opbou van die gemeente. Ook hier word geen omlynde definisie van gemeente-opbou (of verwante tenne) gebied nie.

Bostaande studies het meriete in eie reg. Dit blyk egter dat die definiëring van gemeente-opbou nog nie omvattende aandag geniet het nie.

\section{Die definiëring van gemeente-opbou - 'n onontginde veld?}

Die volgende twee aspekte van gemeente-opbou behoort onses insiens nog deeglik ondersoek te word:

* Die definiëring en afbakening van Gemeente-opbou as vak teenoor die ander dissiplines in Diakoniologie.

* Die definièring en afbakening van gemeente-opbou as bedieningsgestalte teenoor die ander bedieningsgestaltes van die Woord (soos prediking, pastorale bediening, kategese).

\subsection{Twee interpretasies}

Uit bostaande besinning binne die GKSA blyk dit dat "gemeente-opbou/opbou van die kerk" hoofsaaklik op twee maniere geïnterpreteer word:

* Die begrip dui op die groei na volwassenheid in Christus (vgl. die studie van Labuscagne)

- Die begrip dui op die toenusting met die Woord - maar met verskillende toespitsings in byvoorbeeld Liturgiek, Homiletiek, Pastoraat (vgl. die studies van Tiemensma, De Klerk en Combrink).

Daar word nou verder aandag gegee aan 'n duidelik-omlynde definisie van gemeente-opbou 


\subsection{Op soek na die betekenis van die begrip gemeente-opbou}

In die soeke na 'n omlynde definisie van "gemeente-opbou" moet eers aandag gegee word aan die uitgangspunte oor gemeente-opbou. Die term gemeenteopbou in Gereformeerde literatuur word hoofsaaklik verstaan as die resultaat van die effektiewe, Skrifgefundeerde bedieningsgestaltes van die Woord. Daarvolgens is gemeente-opbou gelyk aan die gevolge van effektiewe prediking, pastorale werk en kategese, ensovoorts.

Volgens hierdie uitgangspunt is gemeente-opbou dus nie gelyk aan 'n eiesoortige, planmatige, doelgerigte en samehangende bediening waarin die opbou van die gemeente die primêre blikpunt en doel is nie (vgl. ons voorlopige definisie hieronder, punt 5.1 en 5.3). Wanneer gemeente-opbou egter wel as 'n eiesoortige bedieningswyse beskou word, sal in die praktyk van die herderlike bediening naas en met inkorporering van die prediking, kategese en pastorale werk, ruimte moet wees vir arbeid wat die omvattende op- en uitbou van die gemeente op grond van God se Woord en in ooreenstemming met die gereformeerde belydenis op die oog het. Die dienswerk van die gelowige onder leiding van die besondere dienste sal ten volle by hierdie arbeid betrek word.

Indien gemeente-opbou slegs as die resultaat van die verskillende bedieninge beskou word, bly dit ' $n$ ope vraag of gemeente-opbou erkenning sou kon ontvang as 'n selfstandige bedieningsgestalte van die Woord. Die vraag bly ook of daar dan sprake kan wees van Gemeente-opbou as 'n definieerbare (deel-) dissipline in die teologiese ensiklopedie.

\subsection{Gemeente-opbou as nuwe term}

Te Velde (1992a:18) wys daarop dat gemeente-opbou in sy moderne betekenis in die groot Duitse volkskerk ontstaan het, asook in die Hervormde Kerk in Nederland (Te Velde, 1992a:19). In albei gevalle het die verskynsel van "randkerklikheid" 'n belangrike rol gespeel. Te Velde meen dat in gemeenteopbou primêre aandag aan die "middeveld" gegee word. Met dié term bedoel hy die terrein tussen die eredienste op Sondae en die individuele pastoraat (Te Velde, 1992a:21). Hy verwys na die funksionering van groepe in die gemeente die sestiende-eeuse profesie by Zwingli in Zürich, by Bucer in Straatsburg en by A'Lasco in Londen (Te Velden, 1992a:22; vgl. vir A'Lasco ook Du Toit, 1977:75-97). Dit gaan hier oor die ontwikkeling van die dienswerk van die gelowige in groepe maar ook individueel.

Te Velde (1992a:30) wys ook daarop dat die wesenlike bou-aktiwiteite in die gemeente die prediking, kategese, sakramente, gebed en Bybellees, tug en barmhartigheid is. Waar die Woord en die Gees werk, daar is die opbou van die gemeente fundamenteel en effektief aan die gang. Gemeente-opbou wil verseker 
dat die kerk inderdaad missionêre gemeente is, diakonale gemeente, koinoniale en pastorale gemeente, of in die woorde van die titel van G.L. Goedhart se boek oor hierdie onderwerp: Gemeente opbouw: Om dienende, vierende, lerende en delende gemeente te worden (Goedhart, 1984).

\subsection{Gemeente-opbou as opbou en uitbou}

In die studie van A.G.S. Venter (1986) word onses insiens te skerp onderskeid gemaak tussen "opbou" en "uitbou" asof dit twee verbandhoudende maar losstaande sake is. C.J.H. Venter (1986:1) onderskei tussen gemeente-opbou na "binne" en na "buite". Die navorsing van Buys (1989) het aangetoon dat die verhouding tussen opbou en uitbou in gemeente-opbou so verweefd is en so onderling-afhanklik van mekaar, dat enige skeiding tussen "opbou en uitbou" nie water hou nie, en met moeite verdedig kan word.

Ons wil aan die hand doen dat gemeente-opbou as die omvattende bouwerk na binne (binne die gemeente as liggaam van Christus) en na buite (die uitdra en uitleef van die evangelie) beskou moet word. Dan word die bewaar- en vermeerder-aspekte vall gemeentewees nie teenoor mekaar nie, maar langs mekaar gestel.

\subsection{Gemeente-opbou en toerusting}

Gemeente-opbou in die definisie van Combrink (1993) word weer gelykgestel met "toerusting" van die gelowiges, daarom dat Combrink in staat is om te stel dat alles wat die opbou van die gemeente dien, sonder meer "gemeente-opbou" kan heet. Daarin neem lyy standpunt in teenoor Nel wat handhaaf dat gemeenteopbou nie bloot die somtotaal van hernuwing in prediking, kategese en pastorale sorg (ensovoorts) is nie (Nel, 1986:1).

Gemeente-opbou moet egter nie verskraal word tot die proses van toerusting nie - hoe onmisbaar toerusting in die proses van gemeente-opbou ook mag wees. Toerusting bly uiteindelik slegs ' $n$ onderafdeling van die werksaamhede van die gemeente as Bruid van Christus wat besig is om haarself volgens God se Woord op te bou tot die volheid van God in Christus (vgl. Snyman, 1971:33). Nel en Te Velde se meer omvattende definisies van gemeente-opbou betrek byvoorbeeld ook die aktiewe rol van die gemeente in gemeente-opbou, die funksionering van die gemeente as koinonıa en die amp van die gelowige. J.D. du Toit (1977:94) het reeds in 1911 gewaarsku dat in die aktivering van die lidmaat hy/sy nie in die proses al te veel op die "katkisasiebankie" geplaas moet word nie. 


\section{Op weg na 'n definisie}

\section{1 'n Werkbare (maar voorlopige) definisie}

In hierdie artikel word voorgestel dat die term gemeente-opbou op tweërlei wyse gebruik kan word, naamlik:

* 'n Doelgerigte, omvattende bediening in die plaaslike kerk, naas en met inkorporering van ander bedieningsgestaltes van die Woord (soos prediking, pastorale sorg, kategese). Daardeur word die plaaslike kerk onder leiding van die ampte begelei om die bouwerk van God aan sy kerk te verstaan en daaraan mee te werk in gehoorsaamheid aan God se Woord (vgl. 1 Korintiërs 3; 1 Petrus 2:1-10; Efesiërs 4:7-16), en volgens die Belydenis van die kerk (hier met spesifieke verwysing na die Nederlandse Geloofsbelydenis, artikel 27-35, en die Heidelbergse Kategismus, 21:54). Die spesifieke inhoud van gemeente-opbou as herderlike bediening word hieronder verder aangedui.

* in Wetenskaplike besinning oor die bouwerk van God Drie-enig aan sy kerk, oor die roeping wat God sy kerk oplê om as medewerkers aan sy bouwerk deel te hê, en wat daarmee in direkte verband staan.

\subsection{Defmisies van gemeente-opbou}

Ter wille van volledigheid word ook verwys na definisies van ander teoloë. Bogenoemde definisie sluit baie nou aan by dié van $\mathrm{Nel}$ ( $\mathrm{vgl}$. sy bydraes van $1986: 3,55,1987: 36 ; 1994: 13-14,1994: 99$ voetnoot 41 en 42 ). Nel het 'n toonaangewende rol in Suid-Afrika gespeel in die formulering en definierring van die term gemeentebou. Hy stel 'n omvattende benadering tot gemeentebou voor (Nel, 1994:13). Nel (1994:10-11) argumenteer ten gunste van 'n definisie van gemeentebou waar dit ' $n$ onderskeibare bediening in die plaaslike kerk is. In die opbouwerk is die totale gemeente in sy wese, bestaan, funksionering en strukturering ter sprake.

Nel (1994:14) maak die sinvolle onderskeid tussen gemeentebou as bediening in die plaaslike kerk enersyds, en Gemeentebou as teologiese vak andersyds. Sy definisie lui soos volg:

- Gemeentebou as bediening:

Gemeentebou is die bediening waarbinne die gemeente opgelei en begelei word om:

- $\quad$ sy eie wese en bestaansdoel te verstaan;

- $\quad$ self, as gemotiveerde gemeente, sy eie funksionering te evalueer, doelwitte vir sy doelgerigte funksievervulling te formuleer en op beplande wyse te bereik; 
- self, soos nodig, op 'n voortgaande basis strukture, wat die heilshandelinge van die drie-enige God in kerk en wêreld dien, vir die gemeentelike funksionering te ontwikkel.

* Gemeentebou as teologiese vak:

Oikodomiek of gemeentebou is die wetenskaplike bestudering van die begeleiding van die gemeente tot:

- groeiende insig en verstaan van sy wese (identiteit) en bestaansdoel (teologies hermeneutiese dimensie van die vakafdeling);

- voortgaande verandering of vernuwing tot funksievervulling in ooreenstemming met die gemeente se bestaansdoel (agogies teleologiese dimensie);

- die ontwikkeling van bedieningstrukture wat sy funksionering in lyn met sy bestaansdoel dien (morfologies teleologiese dimensie) (Nel, 1994:99, voetnoot 42).

Hierdie definisies van $\mathrm{Nel}$ is wesenlik dieselfde as die wat hy voorheen in 1986 te boek gestel het $(\mathrm{Nel}, 1986: 3,55)$.

Hendriks (1992:85) definieer gemeentebou soos volg (vgl. egter ook sy bydrae van 1987:22-24; asook die besinning van Louw, 1985:28-42):

Gemeentebou is die werk van die drie-enige God.

* Dit is gefundeer in die uitverkiesende genade van die Almagtige God wat Hom heilshistories-verbondsmatig aan die mens openbaar.

- Dit is gebaseer op die kruisversoening en opstandingsoorwinning van Jesus Christus wat as Hoof van die kerk sy kerk regeer.

* Dit is handelend aanwesig deur die lewegewende. kragdadige werking van die Heilige Gees.

* Die drie-enige God bou sy gemeente deur die dienswerk van gelowiges wat Hy met gawes vir hierdie werk toerus. Die leidinggewende bedieninge speel hierin 'n grondliggende rol.

* Die dienswerk van die gelowiges geskied in die konteks van die liefde, koinonia, gehoorsaamheid, kennis, vrede, orde, vreugde, gebed, getuienis, onderrig, die erediens, geregtigheid, dade van barmhartigheid en die voortgaande proses van stryd.

Gemeentebou het ten doel:

* die kwantitatiewe en kwalitatiewe opbou (dit is: geestelike groei tot volwassenheid, die voorkoming van dwaalleer en betrokke raak by die missio $D e l$ ) van die ekklesia;

- die realisering van die eenheid van die liggaam van Christus;

* die blywende visie op die eskatalogiese hoop van die ekklesia;

- die daarstelling van die ekklesia as 'n voorlopige gestalte van die koninkryk van God;

- die verheerliking van God; 
* die bestudering van die teorie en praktyk van die opbou van die gemeente om die ekklesia as liggaam van Christus in sy geheel en in sy dele te laat funksioneer.

Te Velde definieer gemeente-opbou soos volg (1992:52):

Gemeenteopbou werk aan die koördinering, funksionalisering en optimalisering van alles wat daar in die verskillende vertakkinge van kerklike werk gebeur. Dit het ' $n$ ondersteunende en aanvullende funksie ten opsigte van die amptelike vakke (Praktiese Teologie/Diakoniologie) (Vry vertaal.)

Sy formele definisie wat hy elders aanstip, lui soos volg (Te Velde, 1992:29):

Gemeente-opbou is die werk wat in die Christelike gemeente gedoen word volgens God se opdrag en in sy krag. Hierdie opbou vind plaas op ' $n$ manier waardeur besondere aandag gegee word aan die gawes en take van elke gemeentelid en aan die aktiwiteite in die 'middeveld'. Verder word baie nadruk gelê op goed-georganiseerde, planmatige en doelgerigte aktiwiteite, met gebruikmaking van insigte en metodes uit die menswetenskappe. (Vry vertaal.)

F. Schwartz \& C.A. Schwartz (1987:61) definieer Gemeente-opbou as al daardie handelinge wat die oprigting en vorm-gestaltegewing van die ekklesia dien. Hierdie definisie kan egter eers na waarde geskat word as die onderskeid wat die skrywers tussen "Kirche" en "Ekklesia" handhaaf, in berekening gebring word. By hulle is "Kirche" die kerklike instituut, en "Ekklesia" die ware gelowiges binne die kerk (Schwarz \& Schwartz, 1987:27-41).

Saamgevat: bogenoemde definisies het dit met mekaar in gemeen dat die dienswerk van die gelowige en die funksionering van die gemeente as liggaam van Christus op aarde beklemtoon word. Maar dit blyk ook duidelik dat daar geensins sprake is van 'n eenvormige definisie met dieselfde beklemtoning nie.

\subsection{Gemeente-opbou - die werk van God én van mense}

$\mathrm{Na}$ aanleiding van die oorsig uit Gereformeerde literatuur kom dit voor asof die nodige onderskeidinge nog nie beslissend gemaak is en gebruik word nie Hierdie artikel stel as hipotese dat 'n onderskeid tussen die "opbou van die kerk" en "gemeente-opbou" verhelderend kan wees. Die volgende onderskeid word voorgestel:

* Die opbou van die kerk verwys na die uitverkiesende, vergaderende, bewarende en vermeerderende werk van God Drie-enig deur sy Woord en Gees en deur diegene wat God in sy diens daartoe gebruik. Hierdie werk is in die Ou- en Nuwe-Testamentiese tye deur al die eeue voltrek. 
* Gemeente-opbou verwys na die doelgerigte, omvattende bediening in die plaaslike kerk, naas en met inkorporering van ander bedieningsgestaltes van die Woord waardeur die plaaslike kerk onder leiding van die ampte begelei word om die bouwerk van God aan sy kerk te verstaan en daaraan mee te werk in gehoorsaamheid aan God in sy Woord.

* Gemeente-opbou verwys ook na die teologiese dissipline wat die wetenskaplike bestudering van die bouwerk van God deur die Woord en ampte in beginsel en praktyk (insluitend die diens van die gelowige) as objek het

Dat God mense in sy diens gebruik om die Woord te saai is duidelik uit 'n Skrifgedeelte soos Romeine 10:14-15. Uit Skrifgedeeltes soos 1 Korintiërs 3:9, 1 Petrus 2:5, 9-10 en Efesiërs 4:7-16 is dit ook duidelik dat God mense in sy diens gebruik as medewerkers, as mede-bouers. Die gereformeerde belydenis praat die Skrif getrou na - ook in hierdie opsig. Die Nederlandse Geloofsbelydenis (artikel 27-32) bely op omvattende wyse dat God sy kerk vergader en beskerm van die begin van die wèreld af tot die einde daarvan, en dat elkeen verplig is om hom by die kerk te voeg om die medehuisgenote van God in die opbou van hulle geloof te dien. Die Heidelbergse Kategismus (21:53-55) bely dat Christus deur sy Gees en Woord sy kerk vergader en onderhou. Aangaande die gemeenskap van die heiliges bely dieselfde gedeelte van die Heidelbergse Kategismus dat elke gelowige sy skatte en gawes tot nut en saligheid van die ander gelowiges moet aanwend.

Gemeente-opbou as praktiese bediening in die plaaslike kerk sal (ten minste) aan die volgende sake indringend aandag gee: die bevordering van die Godskennis van elke lidmaat; die skep van toerusgeleenthede soos wat behoeftes deur lidmate onder leiding van die besondere dienste geïdentifiseer word; die groei van die hele gemeente as liggaam van Christus om sy gestalte weer te gee; die bevordering van die gemeente as biddende, lerende, getuigende en evangeliserende gemeenskap. Die ontplooiing van die gawes van die voorgangers asook van die lidmate sal hoë prioriteit geniet, asook die funksionering van die lidmate as profete, priesters en konings. Die medewerking van die gemeente in al hierdie sake sal gesoek word.

In al hierdie sake sal behoudsug sowel as veranderingsdrif vermy moet word. Daarteenoor sal die Gereformeerde gemeente die onmisbare plek van gebed, Skrifstudie en bepeinsing as deugde in die gereformeerde spiritualiteit na waarde skat en as onmisbare beginpunt gebruik, met die eer van God as doksologiese eindmotief as die enigste mikpunt

'n Duideliker definisie as wat blyk uit bestaande besinning van wat met gemeente-opbou bedoel word, sal onses insiens verhelderend inwerk op die verdere nadenke oor hierdie saak. Te Velde (1993a:13-14) is oortuig dat indien 
die bouwerk van God en die mede-arbeid van mense in die kerk reg verstaan word, die term waarmee die arbeid van mense in die opbou van die kerk aangedui word (gemeente-opbou) nie van groot belang is nie. Die moontlikheid van begripsverwarring in dié verband behoort Gereformeerde teoloë egter steeds te maan om versigtig tot 'n groter konsensus van die definisie van gemeente-opbou te kom.

\subsection{Die soewereiniteit van God en verantwoordelikheid van mense}

Die soewereiniteit van God moet deurentyd in Gereformeerde gemeente-opbou onverswak gehandhaaf word. Die evangelie en die verkondiging daarvan mag ook nie verlaag word tot blote veranderingstegnieke nie. God werk soms ook ten spyte van en ondanks sy kinders en sy kerk se ongehoorsaamheid of louheid. God werk egter ook deur sy kinders - en sy werk word des te meer sigbaar daar waar sy kinders gehoorsaam met Hom meewerk in sy opbouwerk. Die verantwoordelikheid van die mens in God se diens moet ewe sterk gehandhaaf word. Die uitdaging vir die Gereformeerde teologie is om die twee sake (God se soewereiniteit en die mens se verantwoordelikheid) in 'n spanninglose, a-polêre (teenoor ' $n$ bipolêre) verhouding te handhaaf in gemeente-opbou.

\section{Die wetenskapstatus van Gemeente-opbou}

\subsection{Instelling van 'n nuwe vak}

Onder die naam Pastoraal 4 (Gemeente-opbou) - Kandidaats + en Th.M. I (DKL 731) word 'n semesterkursus van ongeveer tien klasse van 1986 af by die Teologiese Skool te Potchefstroom aangebied vir teologiese studente in hulle vierde jaar. Volgens die Sillabusdokument van die Fakulteit Teologie van die PU vir $\mathrm{CHO}$ word die kursuseenheidsdoelstelling soos volg uiteengesit: "Na afloop van hierdie kursuseenheid moet die student as aanstaande predikant in staat wees om die beginsels en metodes van gemeente-opbou sinvol te beheers en te kan toepas en ook om op Magistervlak 1 wetenskaplik-krities met toepaslike bronne op die vakgebied van gemeente-opbou om te gaan." Die inhoud van die kursuseenheid (Teologiese Skool van die GKSA, 1995:59) word met die volgende ses punte gestel:

* Skriftuurlike onderbou waaronder die opdrag tot Gemeente-opbou en die charismata waardeur God sy gemeente opbou.

* Bepaling van opboudoelwitte.

* Gemeente-analise met die oog op Gemeente-opbou.

* Diakoniek, toegespits op 'n diakonale gemeente

* Analise van samelewingsveranderinge in die huidige tyd (w.o. politieke veranderinge en waardeverskuiwings). 
* Toerusting van kerkraads- en gemeentelede met die oog op opbou van die gemeente

\subsection{Die noodsaaklikheid om Gemeente-opbou as volwaardige teologiese vak te ontwikkel}

* Met die instelling van die kursus is daar ' $n$ tree gegee in die rigting van die erkenning van Gemeente-opbou as volwaardige teologiese vak of deeldissipline. Hiermee is onses insiens reeds erkenning gegee aan die teologiese ontwikkelinge op die gebied van Gemeente-opbou, en word die nodige stappe gedoen om in hierdie verband voomemende predikante voor te berei op die moeilike taak wat op hulle wag in die praktyk van die herderlike bediening.

* Die wêreldwye teologiese besinning oor Gemeente-opbou maak die formele bestudering daarvan noodsaaklik. Die omvang van die literatuur op hierdie gebied wat in hierdie artikel alleen aangedui is, het die noodsaaklikheid van Gemeente-opbou as teologiese vak bevestig. Ook die Gereformeerde teologie het onses insiens die roeping om op die veld van kerklike funksionering en kerklike vernuwing in die Bybelse sin van die woord (alles deel van Gemeente-opbou) bydraes te lewer en teoloe in hierdie verband toe te rus. Van 't Spijker (1990:311) het reeds opgemerk dat die Reformatore van die sestiende eeu die opbou van die gemeente as die vernaamste doelstelling van die ampte beskou het, en dat die begrip aedificatio ecclesiae in die geskrifte van die Reformatore 'n groot rol gespeel het. 'n Bestudering van die werk van die Reformatore (vgl. Van 't Spijker, 1990:309-332 oor Luther, Bucer en Calvyn; Du Plooy, 1994:1-22 oor A'Lasco) sal die primêre belangstelling van die gereformeerde teologie in die opbou van die gemeente verder bevestig.

* Die werke waama verwys is onder 2.1-2.7 verteenwoordig 'n aantal waardevolle insette oor gemeente-opbou vanuit Gereformeerde geledere Dit is egter noodsaaklik dat hierdie (en ander) bydraes verreken en tot een geheel geïntegreer word in die lig van die problematiek wat in hierdie artikel aangetoon is. Die uitdaging vir teoloè van die GKSA is om die Skriftuurlike begronding van gemeente-opbou na te gaan en opnuut uit te spel met die oog op die bevordering van die gemeente-opbouproses. Daarmee behoort moontlike besware teen gemeente-opbou as 'n "Amerikanisme" finaal besweer te word.

* Tog is daar nog ryk stof wat wag op verdere ontginning in terme van die begronding en uitbou van Gemeente-opbou as teologiese vak. Ander sake wat roep om verdere besinning is die verantwoording oor die wetenskapsteoretiese vertrekpunte van Gemeente-opbou en die ensiklopediese plek van Gemeenteopbou (as Diakoniologiese of as Ekklesiologiese vak). Te Velde (1989:11) en $\mathrm{Nel}$ (1987:26-37) oordeel dat daar in die teologies-ensiklopediese vierdeling 
van Kuyper reeds prinsipieel plek gemaak is vir die vak Gemeente-opbou. Kuyper het vakgebiede soos Kubernetiek (die "bestuur" van die gemeente) en Laiek (die dienswerk van die gelowige) reeds onskryf. Nel (1994:99 voetnota 42) en Te Velde (1992a:52) het reeds die keuse uitgespel ten gunste van Oikodomiek as naam vir hierdie vakgebied. Verdere besinning hieroor in die Gereformeerde teologie is egter noodsaaklik.

* Enige pogings tot reformasie en herlewing in die kerk noodsaak dat die teologiese opleiding van predikante ook toerusting ten opsigte van God se bouwerk aan die kerk bevat. A.N. Hendriks het oor die instelling van Gemeente-opbou aan die Teologiese Skool van Kampen (Broederweg), van die Gereformeerde Kerke (Vrijgemaak) in Nederland, opgemerk dat die doseer van Gemeente-opbou "voor onze aanstaande predikanten, voor de ambtsdragers en voor die gemeenten van veel nut zijn" (Hendriks, 1990:132). Die predikant het teoretiese en praktiese toerusting in dié verband nodig. Die saak van die begronding van Skriftuurlike gemeente-opbou, beplanning in gemeente-opbou, toerusting vir die besondere dienste en vir die dienswerk van alle gelowiges is maar enkele voorbeelde van sake waarin die bedienaar van die Woord vaardig moet wees.

* Die beskrywingspunt oor die dalende lidmaattalle in die GKSA (Handelinge, 1994:618-620) het gelei tot ' $n$ besluit van die Nasionale Sinode van 1994 om die tendens van dalende lidmaattalle te ondersoek, on die oorsake na te vors en om advies ter tafel te neem oor hoe die saak gehanteer kan word. Hierdie sake moet onses insiens direk in verband gebring word met die probleemstelling wat in Gemeente-opbou ondersoek word.

Met hierdie sinodebesluit het die GKSA sy voete op dieselfde pad gesit as die sinodes van twee gereformeerde kerke in Nederland, naamlik die Nederlandse Hervormde Kerk wat hulle bevindinge publiseer in Gemeentevormen en gemeenteopbouw: een bijdrage tot het gesprek (Generale Synode, 1971), en die Gereformeerde Kerken (Synodaal) - vergelyk Te Velde (1992:19). Dit is ook die pad wat kerke (die sogenaamde mainline churches, waaronder die Christian Reformed Church) van Amerika (vgl. Hutcheson, 1981:109-122) en die kerk in Duitsland geloop het (vgl. Te Velde, 1992a:27). Hiermee word nie voorgegee dat die doseer van 'n teologiese vak (Gemeente-opbou) die kerke en die res van die teologie kan of wil red nie (soos Schwarz \& Schwarz [1987:294] wel beweer).

\section{Samevatting en slot}

Die bevinding van hierdie artikel is dat daar reeds beslissende teologiese arbeid oor gemeente-opbou gedoen is in die geledere van die GKSA, maar dat verdere besinning oor gemeente-opbou terselfdertyd noodsaaklik is met die oog op die 
uitbou daarvan. Die definisie van gemeente-opbou en die noodsaak van Gemeente-opbou as teologiese dissipline, asook die Skriftururlike en konfessionele begronding is sake wat verder uitgebou en met groot vrug toegepas kan word.

\section{Bibliografie}

ANON. 1984 Gemeente-opbou Die Kerkblad, 87(2703):3, Okt 3.

BUYS, P.J., red 1983. Gemeentetoerustingskursus Vereeniging : Gereformeerde Kerk Vereeniging

BUYS, P J 1984 Die aard van die verbond en die implikasies daarvan vir evangelisasie Potchefstroom : PU vir CHO (Th.M-verhandeling)

BUYS, P J 1988 Kerkgroei: 'n Kritiese evaluering van die kernaspekte van die Church Growth Movement In dic Skriffig, 22(87):2-16, Sept

BUYS, P.J 1989. Die verhouding tussen gemeenteopbou en evangelisering: 'n eksegetiese ondersoek na die betekenis van tersaaklike woorde in die Nuwe Testament en die implikasies daarvan vir die verhouding tussen die bewaring en vermeerdering van die kerk Potchefstroom : PU vir CHO (Proefskrif - Th D)

BUYS, P J \& VENTER, C J H 1994 Bedieningspatrone wat die assimilasie van nuwe gelowiges in die gemeente bevorder In die Skriflig, 28(3):329-351, Nov.

COETSEE, D C. \& POSTMA, D 1984 Is vernuwing nodig? Die Kerkblad, 86(2690):1-2, Apr 4.

COETZEE, JC 1980. Die armoedige amp of die amp van liefdesgemeenskap? (In Botha, E., Steenberg, D., Taljaard, J, Van der Walt, B.J., Van der Walt, S C, reds. Venster op die kerk 20 lidmate oor die reformasie van die kerk in die jare 80 Reeks F3 Versamelwerke nr. 12. Potchefstroom . IRS p 104-113.)

COETZEE, P J 1959 Die GKSA as 'n reformerende Kerk (In Du Toit, S, Van Wyk de Vries, K. S., Snyman, W.J, Bingle, H J J., Krüger, D.W., Van Straten, P., Kruger, B R., reds Die Gereformeerde Kerk in Suid-Afrika 1859-1959: Gedenkboek by geieentheid van die eeufees. Potchefstroom Eeufeesdeputaatskap van die Algemene Sinode van die GKSA p 277-290)

COMBRINK, V 1987. Die gemeenskap van die heiliges: Bybelse beginsels, praktiese struikelblokke en konkrete patrone (Instituut vir Reformatoriese Studie Reeks Fl, Studiestuk nr 230.)

COMBRINK, V 1993 Die betekenis van die eskatologie in die Kolossensebrief vir gemeenteopbou 'n diakoniologiese ondersoek Potchefstroom PU vir CHO (Proefskrif - Th D)

DE KLERK, TC 1990 Die rol van eredienssang in die opbou van die gemeente Potchefstroom PU vir $\mathrm{CHO}$ (Verhandeling - Th M)

DE KLERK, W J 1959 Kreupel-gelowiges gesprekke oor ons geestelike armoede Potchefstroom Pro Rege

DE KLERK. W J 1964 Wending? Vernuwingsgesprekke oor die Gereformeerde kerkpraktyk Potchefstroom Pro Rege 
DU PLOOY, A le R. 1982 Kerkverband: 'n Gereformeerd-kerkregtelike studie Potchefstroom : PU vir CHO (Proefskrif - Th. D.)

DU PLOOY, J.L. 1994a Die betekenis van die opbouwerk van Johannes a'Lasco: 'n pastorale studie met die oog op die opbou van die kerk (Ongepubliseerde werkstuk ingelewer ter gedeeltelike vervulling van die vereistes vir Th.M., PU vir CHO) Potchefstroom

DU PLOOY, J L 1994b. Die betekenis van gemeente-opbou vir die Gereformeerde Kerke in Suid-Afrika Potchefstroom : PU vir CHO. (Verhandeling - Th. M)

DU TOIT, J D 1977. Die sestiende-eeuse profesie en die betekenis daarvan vir ons tyd. (In Venter, H., red Totius versamelde werke 6 Kaapstad : Tafelberg p. 75-97.)

DUVENAGE, S.C.W 1959. Die amp van die gelowige. (In Du Toit, S., Van Wyk de Vries, K.S., Snyman, W.J., Bingle, H J.J., Krüger, D W., Van Straten, P., Kruger, B R., reds. Die Gereformeerde Kerk in Suid-Afrika 1859-1959: Gedenkboek by geleentheid van die eeufees. Potchefstroom : Eeufeesdeputaatskap van die Algemene Sinode van die GKSA p. 173-188.)

ERASMUS, L.M. 1994. Sola ecclesia? 'n Kritiese verantwoording van die kerkbegrip van die gemeentebouteologie in die Nederduitse Gereformeerde Kerk Bloemfontein UOVS. (Proefskrif - D.Th.)

FLOOR, L. 1971. The general priesthood of believers in the epistle to the Hebrews Neotestamentica, 5:72-82

GENERALE SYNODE DER NEDERLANDSE HERVORMDE KERK 1971 Gemeentevormen en gemeenteopbouw: een bijdrage tot het gesprek 's-Gravenhage : Boekencentrum N.V.

GOEDHART, GL 1984 Gemeenteopbouw: om dienende, vierende, lerende en delende gemeente te worden Kampen: Kok

HANDELINGE VAN DIE VYF-EN-VEERTIGSTE NASIONALE SINODE VAN DIE GKSA, 1994

HENDRIKS, AN. 1990 Die alles in allen volmaakt: een bundel praktisch-theologische opstellen Haarlem : AcaMedia

HENDRIKS, H.J. 1987. 'n Teologies-prinsipiële begronding vir die opbou van die gemeente ( $I n$ Smuts, A J, red Praktiese Teologie in Suid-Afrika 2 Gemeentebou. Pretoria : NG Kerkboekhandel Transvaal p 1-25.)

HENDRIKS, H J. 1992. Strategiese beplanning in die gemeente: die beginsels en praktyk van gemeentevernuwing Wellington: Hugenote

HUTCHESON, R.G. 1981 Mainline churches and the evangelicals Atlanta : John Knox

LABUSCAGNE, G.C.P. 1988 Die plek en betekenis van die prediking in die opbou van die gemeente Potchefstroom: PU vir CHO (Proefskrif - Th D)

LOUW, D J 1985 Die opbou van die gemeente in 'n veranderende samelewing ( $/$ Louw, D.J., red. Op die breuklyn: 'n feesbundel saamgestel ter herdenking van die 125 -jarige bestaan van die Teologiese Seminarium Stellenbosch Kaapstad NG Kerkuitgewers p. 20-42.) 
MALAN, J. 1979. Die plek van die besondere ampte in die opbou van die gemeente - met besondere verwysing na die amp van die gelowiges Potchefstroom : PU vir $\mathrm{CHO}$ (Ongepubliseerde werkstuk voorgelê in die vierde studiejaar vir die graad Th.B.)

NEL, M 1986 Teologiese perspektiewe op gemeentebou. Pretoria : NG Kerkboekhandel Transvaal (Universiteit Pretoria Teologiese Studies, 2.)

NEL, M. 1987. Die verhouding van gemeentebou tot die ander dissiplines van die vak Praktiese Teologie en ander teologiese vakke. (In Smuts, A.J., red Praktiese Teologie in Suid-Afrika 2: Gemeentebou Pretoria : NG Kerkboekhandel p 26-37.)

NEL, M 1994 Gemeentebou Halfway House Orion

OOSTENBRINK, J W. 1994. Kleingroepevangelisering in die stad Potchefstroom : PU vir CHO (Verhandeling - Th M)

SCHULZE, LF 1980. Is die Gereformeerde kerk nog gesond? (3) "Vernuwing" of Skriftuurlike gemeente-opbou? Die Kerkblad, 82(2537) 3, Feb 20

SCHWARZ, F \& SCHWARZ, C A 1987. Theologie des Gemeindeaufbaus. NeukirchenVluyn : Aussaat Verlag

SNYMAN, P C 1971 'n Ontleding van die prediking in die Nuwe Testament met die oog op die opbou van die kerk as missionère probleem In die Skriflig, 5(20) 21-38, Des

SNYMAN, W.J. 1977. Die gebruik van die woord "kerk" in die Nuwe Testament (In Snyman, P C., red Nuwe en ou dinge uit die skat van die koninkryk Potchefstroom : Pro Rege p 35-50.)

SPOELSTRA, B 1984 Gereformeerde kerkbegrip en kerklidmaatskap In die Skriflig. $18(70)$ 20-32, Julie

SPOELSTRA, B 1986 Het ons kerkwees in strukture gestol? In die Skriflig, 20(80) 4-17, Desember

SPOELSTRA, B 1991 Die plek van Kerkreg en Diakoniologie in die teologiese ensiklopedie In dic Skriflig, 26(2) 206-226

SPOELSTRA, B 1992. Dilemma tussen Praktiese Teologie en Ekklesiologie. Theologia Reformata, 35(4) 299-320, Des

SPOELSTRA, B 1994. Die taak van die kerk na binne (Referaat gelewer op 1 Aug 1994 voor die Gereformeerde Teologiese Vereniging ) Pretoria

TEOLOGIESE SKOOL VAN DIE GKSA TE POTCHEFSTROOM 1995 Sillabusdokument Kandidaats en Th B Potchefstroom : TSP.

TE VELDE, M 1989 Gereformeerde gemeenteopbouw. Een eerste koersbepaling voor een nieuw theologisch vak. Barneveld De Vuurbaak

TE VELDE. M 1992 Gemeenteopbouw I Doelgericht en samehangend werken in de christelijke gemeente Barneveld De Vuurbak Tweede druk

TE VELDE, M 1993 Gemeenteopbouw 3: Methodisch beleid ontwikkelen in de christelijke gemeente Barneveld De Vuubaak

TIEMENSMA. E J 1989 Huweliksorg in gemeente-opbou geloofsgroei as grond en inhoud van die pastorale begeleiding van man en vrou in die huwelik Potchefstroom PU vir CHO (Verhandeling - Th M ) 
VAN DER WALT, IJ 1985. Die evangelie aan afgedwaaldes Handleiding vir evangelisasie Potchefstroom : Universum.

VAN DER WALT, JJ. 1976. Christus as Hoof van die Kerk en die presbiteriale kerkregering. (In Wetenskaplike Bydraes van die PU vir CHO. Potchefstroom : Pro Rege Reeks A: Geesteswetenskappe, Nr. 21)

VAN DER WALT, J J. 1981 Die verhouding van die diakoniologie tot die ander teologiese dissiplines (In Nel, M, red. Die kerk se werk: kongresreferate van die Werkgemeenskap vir Praktiese Teologie 1979 en 1980. Pretoria : UP. p. 20-31)

VAN DER WALT, J.J 1986. Teen hierdie stroming die kerk. (In Onderskeiding van die geeste Potchefstroom : Instituut vir Reformatoriese Studies. Wetenskaplike bydraes van die PU vir CHO: Reeks F3, nr. 26, p. 126-139.)

VAN DER WALT, N. 1983. Eenheid of eensaamheid - oor die gemeenskap van die gelowiges. (In Botha, E., Steenberg, D., Taljaard, J., Van der Walt, B.J., Van der Walt, S.C., reds. Venster op die kerk. 20 lidmate oor die reformasie van die kerk in die jare 80. Reeks F3: Versamelwerke nr 12. Potchefstroom : IRS p. 20-28. Tweede druk.)

VAN ROOY, J A 1984a. Is die kerk dood? Die Kerkblad, 87(2692): I-2, Mei 2

VAN ROOY, J A 1984b. Is die kerk dood? Die Kerkblad, 87(2693) 1-2, Mei 16

VAN 't SPIJKER, W. 1990. Aspecten van gemeenteopbouw in de Reformatie. Theologia Reformala, 33(4);309-332, Des

VENTER, A.G.S 1986 Die werk van die Heilige Gees in die opbou van die kerk volgens Handelinge Potchefstroom: PU vir CHO (Proefskrif - Th D)

VENTER, C.J.H 1986. Gemeente-opbou in die lig van Hebreers Potchefstroom PU vir CHO (Reeks H: Inougurele Rede nr. 13.)

VENTER, C.J.H 1988a. 'n Nuwe-Testamentiese profiel van 'n gemeente wat homself opbou (In Venter, C.J.H., red. God bou op deur sy Woord. Potchefstroom : PU vir CHO p. 10-27.)

VENTER, C.J.H. red. 1988 b God bou op deur sy Woord Potchefstroom : PU vir CHO 